\title{
Successful implementation of ChIP-seq antibody quality control at Diagenode using automated ChIP protocol on the SX-8G IP-Star ${ }^{\circledR}$ Compact
}

\author{
Ignacio Mazon ${ }^{2 *}$, Sharon Squazzo ${ }^{2}$, Jan Hendrickx', Géraldine Goens ${ }^{1}$, Catherine D'andrea', Geoffrey Berguet ${ }^{1}$, \\ Celine Sabatel ${ }^{1}$, Miklos Laczik', Dominique Poncelet ${ }^{1}$
}

From Epigenetics \& Chromatin: Interactions and processes

Boston, MA, USA. 11-13 March 2013

Chromatin immunoprecipitation (ChIP) is the most widely used method to study protein-DNA interactions. A successful ChIP, however, is largely depending on the use of well characterized, highly specific ChIP-grade antibodies.

ChIP-seq has become the gold standard for whole-genome mapping of protein-DNA interactions. The generalized adoption of this technology is currently limited by four main technical hurdles. First, the reproducibility and biological relevance of DNA-associated protein landscapes depend on the specificity and performance of the antibodies in the context for which they are used. Second, the ChIP-seq method requires optimized protocols ensuring high recovery and increased signal-to-noise ratio. Third, as an effort to reduce the cost per sample and improve reproducibility, the ChIP-seq method should be compatible with automation. Finally, the economical and widespread use of ChIP-seq requires access to a fast and high value/ quality next-generation sequencing platform. Here, we demonstrate the successful use of the Diagenode integrated line of products to establish a $\mathrm{QC}$ procedure to qualify antibodies and standardize ChIP-seq experiments.

\section{Author details \\ 'Diagenode S.A., CHU, Tour GIGA B34, 3ème étage 1 Avenue de l'Hôpital, 4000 Liège, Sart-Tilman, Belgium. ${ }^{2}$ Diagenode Inc., 400 Morris Avenue, Suite 101, Denville, NJ 07834, USA}

Published: 8 April 2013

2Diagenode Inc., 400 Morris Avenue, Suite 101, Denville, NJ 07834, USA

Full list of author information is available at the end of the article
doi:10.1186/1756-8935-6-S1-P133

Cite this article as: Mazon et al:: Successful implementation of ChIP-seq antibody quality control at Diagenode using automated ChIP protocol on the SX-8G IP-Star ${ }^{\circledast}$ Compact. Epigentics \& Chromatin 2013 6(Suppl 1): P133.
Submit your next manuscript to BioMed Central and take full advantage of:

- Convenient online submission

- Thorough peer review

- No space constraints or color figure charges

- Immediate publication on acceptance

- Inclusion in PubMed, CAS, Scopus and Google Scholar

- Research which is freely available for redistribution 